\title{
Algal-bacterial treatment facility removes selenium from drainage water
}

\author{
Nigel W.T.Quinn \\ Tryg J. Lundquist \\ - F. Bailey Green \\ 口 Max A. Zárate \\ a William J. Oswald
}

Terrance Leighton

\begin{abstract}
A demonstration algal-bacterial selenium removal (ABSR) facility has been treating agricultural drainage water in the Panoche Drainage District on the west side of the San Joaquin Valley since 1997. The project goals are to demonstrate the effectiveness of the ABSR technology for selenium removal, to investigate potential wildlife exposure to selenium at full-scale facilities, and to develop an operational plant configuration that will minimize the life-cycle cost for each pound of selenium removed. The facility consists of a series of ponds designed to promote native microorganisms that remove nitrate and selenium. Previous treatment research efforts sought to reduce selenium concentrations to less than $5 \mu \mathrm{g} / \mathrm{L}$, but the ABSR Facility demonstration focuses on providing affordable reduction of the selenium load that is discharged to the San Joaquin River. During 1997 and 1998, the best-performing ABSR plant configuration reduced nitrate by more than $95 \%$ and reduced total soluble selenium mass by $80 \%$. Ongoing investigations focus on optimizing operational parameters and determining operational costs and scale-up engineering requirements. The preliminary total cost estimate for a 10-acre-foot per day ABSR facility is less than $\$ 200$ per acre-foot of treated drainage water.
\end{abstract}

Agricultural drainage water treatment for selenium removal has been an active area of research for over a decade, since the discovery of deformed waterfowl embryos at Kesterson Reservoir in the western San Joaquin Valley (Ohlendorf et al. 1986). So far no treatment technology has proven economically feasible for meeting the $5 \mu \mathrm{g} / \mathrm{L}$ State Water Resources Control Board objective for selenium discharged to receiving waters such as the San Joaquin River and Mud Slough (SWRCB 1989; EPA 1987). Agricultural drainage discharged into Mud Slough from the Grasslands Basin exceeds this concentration regularly (CVRWQCB 1999).

Since the authorization of the Grassland Bypass Project in 1996 (Quinn et al. 1998), the regulatory approach has shifted from meeting concentration objectives to reducing selenium load. The Grassland Bypass Project is a 5-year experiment, currently in its fourth year, involving Grassland Basin water districts, the U.S. Bureau of Reclamation, California Department of Fish and Game, U.S. Fish and Wildlife Service and U.S. Environmental Protection Agency, which established a schedule of selenium load targets for agricultural tile drainage discharged to Mud Slough and the San Joaquin River. The Grassland Basin farmers agreed to these monthly and annual selenium load targets, which decline by $5 \%$ each year after the second year of the project. Exceeding the targets could lead to fees of up to $\$ 500,000$ per year levied against the participating drainage districts (Quinn et al. 1998).
This policy of monthly and annual load targets has injected new life into the quest for affordable selenium treatment technologies by changing the immediate goals of drainage treatment. The expensive polishing processes required to achieve $5 \mu \mathrm{g} / \mathrm{L}$ are no longer obligatory in treatment systems designed for selenium load reduction. Biological treatment processes may become the most cost-effective solution to the selenium drainage problem in the Grasslands Basin after source control, if expensive external feedstocks can be minimized (table 1).

One simple biological treatment technology is the pond-based AlgalBacterial Selenium Removal (ABSR) technology, which was proposed by Professor William J. Oswald of UC Berkeley (Oswald 1985) and tested on a pilot scale (Gerhardt and Oswald 1990; Gerhardt et al. 1991; Lundquist et al. 1994). It now operates on a demonstration scale at Enrico Farms in the Panoche Drainage District (PDD). The current project is a collaboration among the PDD and engineers, microbiologists and chemists from UC Berkeley and Lawrence Berkeley National Laboratory. The project will show the potential of the ABSR technology to affordably reduce selenium loads from a single subsurface drainage sump yielding the highest selenium loads of any sump in the PDD.

\section{Treatment technologies}

The ABSR process is a specialized application of the effective and economical wastewater treatment technology known as the Advanced Inte- 
Top, Flow splitter and measurement box adjacent to the high-rate pond of the mode 2, molasses fed, algal-bacterial selenium reduction system. Bottom, Alternate view of high-rate pond showing paddle wheel and reduction pond to the right.

grated Wastewater Pond Systems (AIWPS) technology, which has been implemented at full scale for sewage and industrial wastewater treatment by Professor Oswald and his coworkers over the past 32 years (Oswald 1990). Components of the AIWPS technology have also been used for decades at farms that produce algae for pharmaceutical, food dye and health food markets.

The chemical transformations involved in reducing selenium are different from those required for wastewater treatment or for food-grade algae production, but many of the treatment steps and pond designs are similar. Therefore the design, construction and costs of proposed largescale ABSR facilities will be similar to those of the well-established AIWPS technology.

\section{Treatment mechanisms}

The main components of the ABSR technology are two types of ponds in series - reduction ponds (RPs) and high-rate ponds (HRPs) - each designed to foster native bacteria and algae needed for drainage water treatment. Additional units for algae harvesting and water clarification may also be required, such as an algae settling pond or a dissolved air flotation unit.

Nearly all of the selenium (Se) in drainage water is part of the highly soluble ion selenate $\left(\mathrm{SeO}_{6}{ }^{2-}\right)$, in concentrations typically ranging from 100 $\mu \mathrm{g} / \mathrm{L}$ to $600 \mu \mathrm{g} / \mathrm{L}$ as selenium. In the $\mathrm{RPs}$, bacteria convert selenate to insoluble precipitates or take up sele-
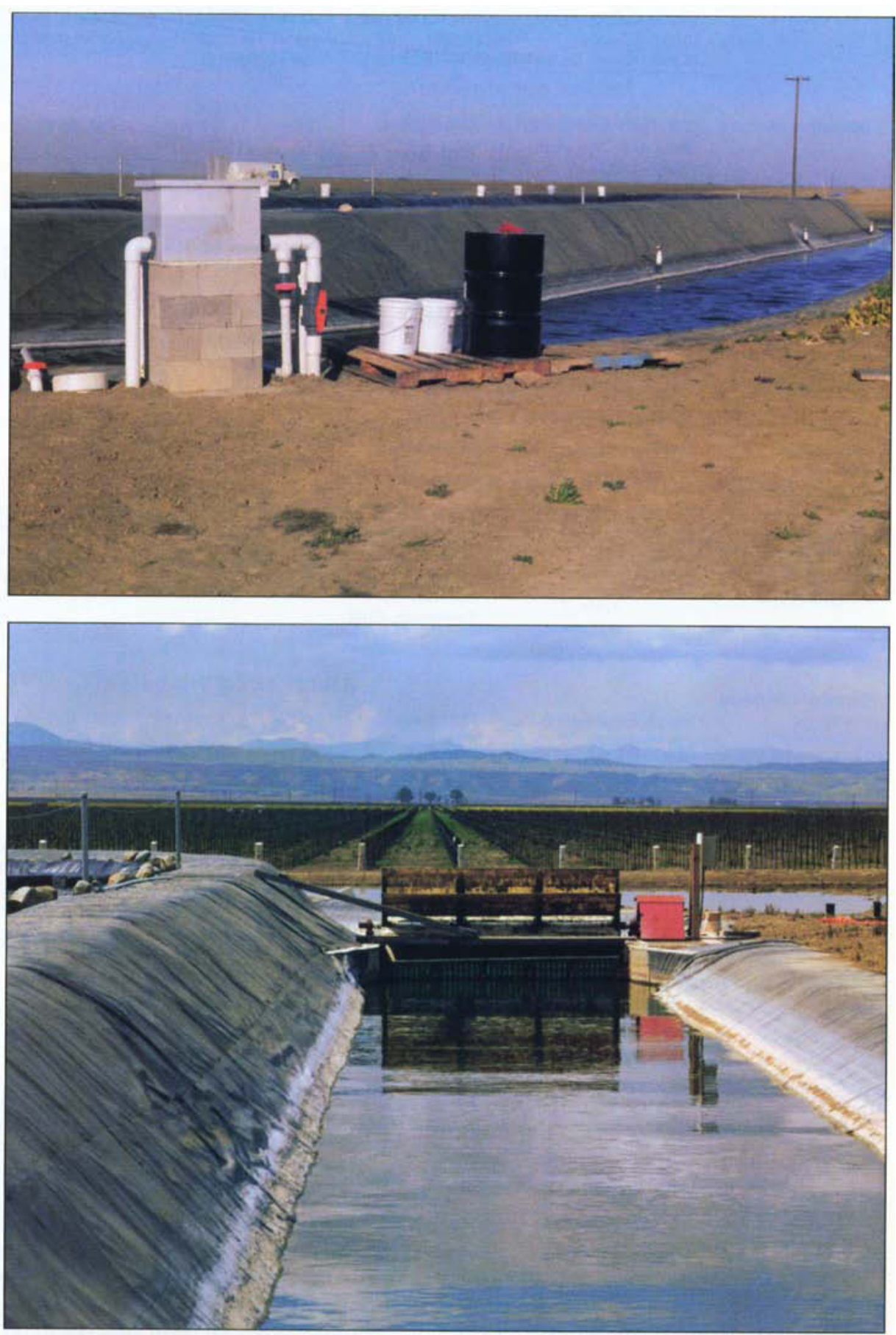

nium in their cells. Much of the insoluble selenium settles in the RPs, and any particulate selenium remaining in the effluent can be removed from the water with dissolved air flotation.

Selenate cannot be reduced to low levels in the ABSR process unless dissolved oxygen $\left(\mathrm{O}_{2}\right)$, nitrate $\left(\mathrm{NO}_{3}{ }^{-}\right)$and nitrite $\left(\mathrm{NO}_{2}{ }^{-}\right)$are also removed (Gerhardt et al. 1991). (Nitrite concentrations were at least 10 times lower than nitrate concentrations in the ABSR Facility. Both compounds were determined using a single analytical method. Therefore the term nitrate refers to the sum of nitrate and nitrite in this study.) 
TABLE 1. Comparison of various drainage treatment processes

\begin{tabular}{|c|c|c|c|c|c|c|}
\hline $\begin{array}{l}\text { Drainage } \\
\text { treatment }\end{array}$ & $\begin{array}{c}\text { Developer/researcher } \\
\text { (experience) }\end{array}$ & Size/location & $\begin{array}{c}\text { Performance } \\
\text { (selenium removal) }\end{array}$ & Cost & Disposal & Comments \\
\hline \multicolumn{7}{|l|}{ Biological } \\
\hline Anaerobic-bacterial & $\begin{array}{l}\text { EPOC Agricultural Corp. } \\
\text { Binnie California Inc. } \\
\text { (1987-present) }\end{array}$ & $\begin{array}{l}24,000 \text { gpd, } \\
\text { Westlands Water } \\
\text { District, Calif. }\end{array}$ & $\begin{array}{l}\text { From } 300-500 \mathrm{ppb} \\
\text { to } 16 \text { to } 50 \mathrm{ppb} \\
\text { (to }<10 \mathrm{ppb} \text { with } \\
\text { ion exchange). }\end{array}$ & $\begin{array}{l}\text { \$244/acre-1 mgd plant; } \\
\$ 145-\$ 165 / \text { acre } \\
\text { for } 10 \text { mgd plant. }\end{array}$ & $\begin{array}{l}\text { Truck to } \\
\text { hazardous waste } \\
\text { facility at } \\
\text { Kettleman Hills } \\
\text { (\$110 per ton). }\end{array}$ & $\begin{array}{l}\text { Use of } \\
\text { methanol as a } \\
\text { food source for } \\
\text { bacteria. }\end{array}$ \\
\hline Facultative-bacterial & $\begin{array}{l}\text { U.S. Bureau of Mines } \\
\text { Salt Lake City, Utah } \\
(1987-1990)\end{array}$ & $\begin{array}{l}\text { Bench scale, } \\
\text { Salt Lake City, } \\
\text { Utah }\end{array}$ & $87 \%-96 \%$ removal. & Unknown & $\begin{array}{l}\text { Truck to hazardous } \\
\text { waste site. }\end{array}$ & $\begin{array}{l}\text { Requires } \\
\text { organic } \\
\text { energy/food } \\
\text { source for } \\
\text { bacteria. }\end{array}$ \\
\hline Microalgal-bacterial & $\begin{array}{l}\text { UC Berkeley } \\
\text { (1986-present) }\end{array}$ & $\begin{array}{l}\text { Pilot scale, } \\
\text { Murietta Farms, } \\
\text { Mendota, Calif. }\end{array}$ & $\begin{array}{l}\text { From } 300-500 \mathrm{ppb} \\
\text { to } 80-100 \mathrm{ppb} \text {, } \\
\text { with } \mathrm{FeCl} 3 \\
\text { polishing-10 ppb. }\end{array}$ & $\begin{array}{l}\$ 272 / \text { acre-ft-1 mgd; } \\
\$ 104 / \text { acre-ft-10 mgd. }\end{array}$ & $\begin{array}{l}\text { Soil amendment } \\
\text { or truck to } \\
\text { hazardous waste } \\
\text { facility. Selenium } \\
\text { recovery possible. }\end{array}$ & $\begin{array}{l}\text { Algae provide } \\
\text { energy/food } \\
\text { for bacteria. } \\
\text { Removal of } \\
\text { nitrate from } \\
\text { drainage with } \\
\text { selenium. }\end{array}$ \\
\hline $\begin{array}{l}\text { Microbial } \\
\text { volatilization } \\
\text { of selenium in } \\
\text { evaporation ponds }\end{array}$ & $\begin{array}{l}\text { UC Riverside } \\
(1987-1991)\end{array}$ & $\begin{array}{l}\text { Laboratory study, } \\
\text { UC Riverside }\end{array}$ & Approximately $23 \%$. & Unknown & $\begin{array}{l}\text { No residual waste } \\
\text { product. }\end{array}$ & $\begin{array}{l}\text { Still } \\
\text { conceptual. }\end{array}$ \\
\hline $\begin{array}{l}\text { Microbial } \\
\text { volatilization of } \\
\text { selenium in soils } \\
\text { and sediments }\end{array}$ & $\begin{array}{l}\text { UC Riverside } \\
(1987-1991)\end{array}$ & $\begin{array}{l}\text { Small field plots, } \\
\text { each less } \\
\text { than one meter } \\
\text { square, } \\
\text { Kesterson, Calif. }\end{array}$ & $\begin{array}{l}\text { From } 11 \% \text { to } 51 \% \\
\text { with addition } \\
\text { of pectin. }\end{array}$ & $\begin{array}{l}\$ 267 / \text { acre-ft assuming } \\
100 \text { ppb Se drainage } \\
\text { and land income } \\
\text { loss } \$ 50 / \text { acre. }\end{array}$ & $\begin{array}{l}\text { No residual waste } \\
\text { product. }\end{array}$ & $\begin{array}{l}\text { Rates slow } \\
\text { down } \\
\text { significantly } \\
\text { after initial } \\
\text { high rates of } \\
\text { selenium } \\
\text { methylation. }\end{array}$ \\
\hline $\begin{array}{l}\text { Physical-chemical } \\
\text { Iron filings }\end{array}$ & $\begin{array}{l}\text { Harza Engineering Inc. } \\
(1985-1988)\end{array}$ & $\begin{array}{l}\text { Pilot scale, } \\
\text { Panoche Water } \\
\text { District, Calif. }\end{array}$ & $50 \%-75 \%$ removal. & $\begin{array}{l}\$ 60 / \text { acre }-50 \% \text { removal; } \\
\$ 120 / \text { acre- } 75 \% \text { removal; } \\
\text { disposal costs ignored. }\end{array}$ & Not estimated. & $\begin{array}{l}\text { Problems with } \\
\text { bed clogging } \\
\text { and channeling } \\
\text { due to poor } \\
\text { pH control. }\end{array}$ \\
\hline Ferrous hydroxide & $\begin{array}{l}\text { U.S. Bureau of } \\
\text { Reclamation } \\
(1985-1989)\end{array}$ & $\begin{array}{l}\text { Bench scale, } \\
\text { E\&R Center, } \\
\text { Denver, Col. }\end{array}$ & $\begin{array}{l}\text { From } 79 \text { to } 90 \mu \mathrm{g} / \mathrm{l} \\
\text { to less than } 1 \mu \mathrm{g} / \mathrm{l} \text {. }\end{array}$ & $\begin{array}{l}\$ 70 \text { to } \$ 182 / \text { acre- } \mathrm{ft} \text {; } \\
\$ 200 \text { to } \$ 250 / \text { acre- } \mathrm{ft} \\
\text { for high nitrate. } \\
\text { Disposal cost ignored. }\end{array}$ & $\begin{array}{l}\text { Disposal in a } \\
\text { hazardous waste } \\
\text { facility. }\end{array}$ & $\begin{array}{l}\text { Nitrate } \\
\text { removal adds } \\
\text { to system cost } \\
\text { and affects } \\
\text { performance. }\end{array}$ \\
\hline Ion exchange & $\begin{array}{l}\text { Boyle Engineering Corp. } \\
\text { (1985-1986) }\end{array}$ & $\begin{array}{l}\text { Laboratory } \\
\text { columns }\end{array}$ & $\begin{array}{l}\text { Use as a polishing } \\
\text { step. Depends on } \\
\text { influent water. }\end{array}$ & Unknown & $\begin{array}{l}\text { Disposal in a } \\
\text { hazardous waste } \\
\text { facility. }\end{array}$ & $\begin{array}{l}\text { Subject to } \\
\text { fouling and } \\
\text { expensive. Not } \\
\text { demonstrated } \\
\text { on a field scale. }\end{array}$ \\
\hline Reverse osmosis & $\begin{array}{l}\text { CH2M-Hill, DWR } \\
(1986-1987)\end{array}$ & $\begin{array}{l}\text { Prototype plant, } \\
\text { (DWR) Los Banos } \\
\text { desalting facility }\end{array}$ & $\begin{array}{l}95 \% \text { removal; } \\
\text { from } 150-200 \mathrm{ppb} \\
\text { to } 10-20 \mathrm{ppb} \text {. }\end{array}$ & $\begin{array}{l}\$ 1,090 / \text { acre- } \mathrm{ft} \text { for } \\
10 \mathrm{mgd} \text { plant plus } \\
\$ 560 / \text { acre-ft for disposal. }\end{array}$ & $\begin{array}{l}\text { Disposal in a } \\
\text { hazardous waste } \\
\text { facility. }\end{array}$ & $\begin{array}{l}\text { Expensive. } \\
\text { Boron } \\
\text { concentration is } \\
\text { not reduced- } \\
\text { remains at } 7-8 \\
\text { ppb. }\end{array}$ \\
\hline $\begin{array}{l}\text { Desalinization with } \\
\text { cogeneration }\end{array}$ & $\begin{array}{l}\text { Resource Management } \\
\text { Inc. (1988-1989) }\end{array}$ & Paper study & $\begin{array}{l}95 \% \text { removal; } \\
\text { from } 150-200 \mathrm{ppb} \\
\text { to } 10-20 \mathrm{ppb} \text {. }\end{array}$ & $\begin{array}{l}\$ 1,500 / \text { acre-ft for } 10 \\
\text { mgd plant plus energy } \\
\text { costs. }\end{array}$ & $\begin{array}{l}\text { Ultimate disposal } \\
\text { of brine in a } \\
\text { hazardous waste } \\
\text { facility. Smaller } \\
\text { volume of waste. }\end{array}$ & $\begin{array}{l}\text { Expensive. } \\
\text { Boron } \\
\text { concentration } \\
\text { is not reduced - } \\
\text { remains at } 7-8 \\
\text { ppb. }\end{array}$ \\
\hline \multicolumn{7}{|l|}{ Agronomic } \\
\hline Agroforestry & $\begin{array}{l}\text { California Dept. of Food } \\
\text { and Agriculture } \\
\text { (1986-present) }\end{array}$ & $\begin{array}{l}\text { Field scale, } \\
\text { Murietta farms, } \\
\text { Calif. }\end{array}$ & $\begin{array}{l}\text { Minimal removal, } \\
\text { some uptake in } \\
\text { trees and by } \\
\text { volatilization } \\
\text { via tree roots. }\end{array}$ & $\begin{array}{l}\$ 108 / \text { acre-assume } \\
\text { harvest costs = revenue } \\
\text { from trees sold for fuel. }\end{array}$ & $\begin{array}{l}\text { Reduces the } \\
\text { volume of drainage } \\
\text { water for disposal. }\end{array}$ & $\begin{array}{l}\text { Does not } \\
\text { remove } \\
\text { significant trace } \\
\text { elements from } \\
\text { drainage; } \\
\text { merely } \\
\text { increases } \\
\text { concentration. }\end{array}$ \\
\hline
\end{tabular}


When biodegradable carbon is present, oxygen is converted to carbon dioxide $\left(\mathrm{CO}_{2}\right)$ and nitrate is converted to nitrogen gas $\left(\mathrm{N}_{2}\right)$ during respiration of microorganisms at the bottom of the RPs. The RPs are sufficiently deep or covered to exclude atmospheric oxygen from a large part of their volume. Since nitrate concentrations in drainage water are often as high as $90 \mathrm{mg} / \mathrm{L}$ as $\mathrm{N}$, compared to $<0.5 \mathrm{mg} / \mathrm{L}$ for selenium, the carbon requirement for nitrate reduction far exceeds that for selenium reduction. Despite high sulfate concentrations $(2,000 \mathrm{mg} / \mathrm{L}$ to 4,000 $\mathrm{mg} / \mathrm{L}$ as $\mathrm{SO}_{4}{ }^{2-}$ ) in drainage water, sulfate does not appreciably interfere with nitrate or selenium reduction.

Nitrate is also removed by a second means in the ABSR technology. Microscopic algae grow in the HRPs, using the nitrate as fertilizer. HRPs are shallow, continuously mixed raceways designed to maximize algal productivity and bacterial oxidation of dissolved organic matter (Oswald 1988). In HRPs, algal productivity typically ranges from 15 to 30 tons dry weight/ acre/year. In comparison, the productivity of crops such as rice, wheat, corn and soybeans rarely exceeds 2 to 3 tons/acre/year. Continuous lowspeed paddle-wheel mixing of HRPs requires only 5 to $10 \mathrm{kWh} /$ acre/day, and beyond promoting high productivity, the gentle mixing of HRPs enhances the selection of algal species that tend to settle when introduced into the quiescent algae settling ponds. The settled algae form a thick slurry that is pumped into the anoxic zone of the RPs. There the algae become a carbon feedstock for bacteria, decreasing or eliminating the need for supplemental feedstocks.

Although algae can use carbon from natural alkalinity, the algal growth rate in HRPs is enhanced by the addition of carbon dioxide. There are at least two practical carbon dioxide sources for HRPs treating drainage water: (1) $\mathrm{CO}_{2}$ produced during bacterial respiration in the RPs and (2) bubbling of exhaust gas from on-site power or heat generation units. Pure carbon dioxide has been used since 1983 as a carbon source in HRPs used for commercial algal cultivation in the

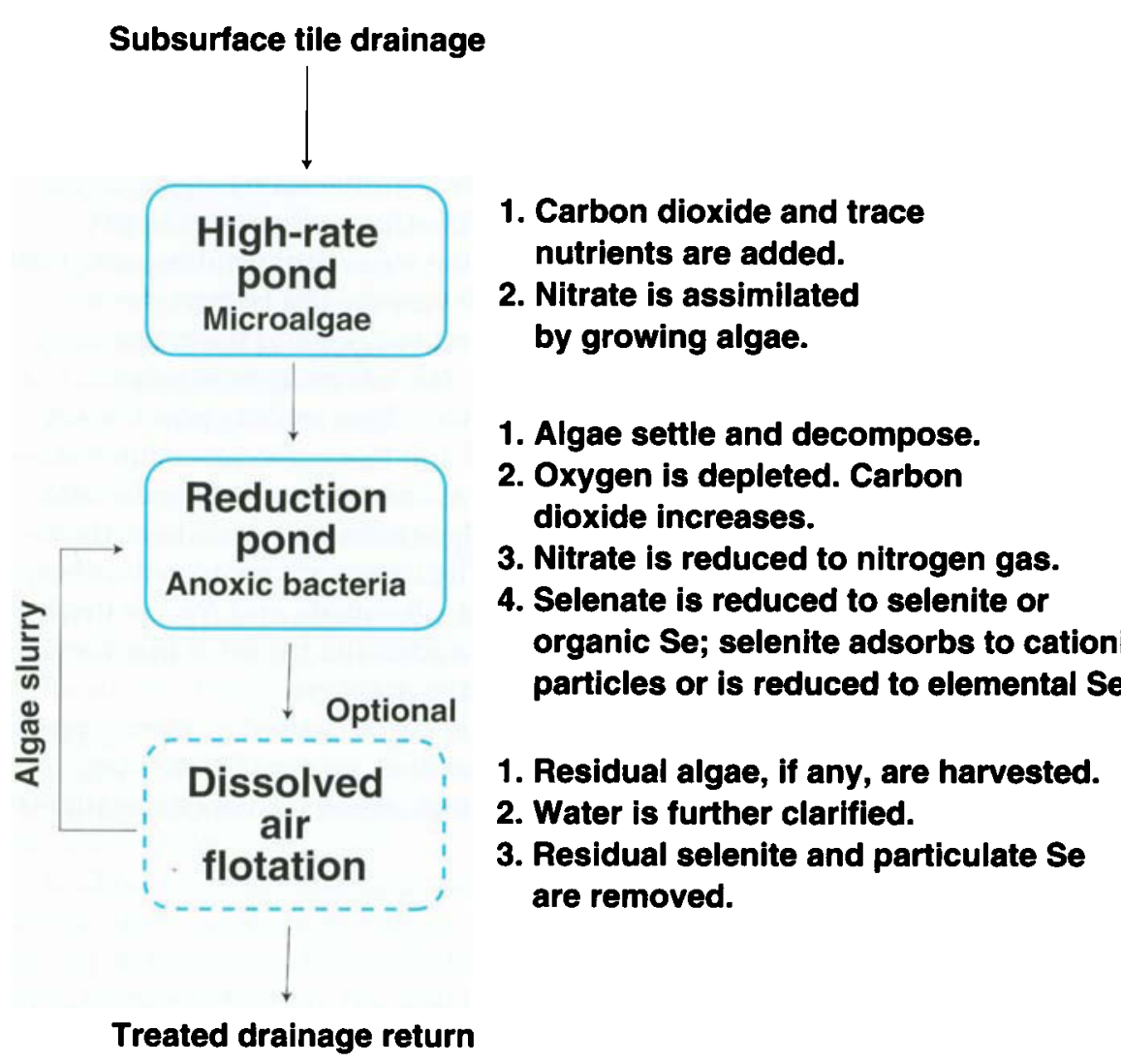

Fig. 1. Schematic of the algal-bacterial selenium removal (ABSR) technology operated in mode 1 , the low-cost configuration receiving only algae feedstock.

Imperial Valley (personal communication, T. Naylor, Microbio Resources, Inc., San Diego).

Selenium removed from the water column accumulates in settled algalbacterial biomass and inert materials on the floor of the RPs. This biomass is continuously undergoing anaerobic decomposition, so the volume of solid residues increases slowly over many years. Removal and disposal of the solids in a landfill should not be required for many years, if not for several decades. Alternatively, the inert solids, which contain nitrogen and phosphorus as well as selenium, might be dried and used as a soil amendment and fertilizer in the eastern Central Valley, where the soils are selenium deficient. Data we have collected so far indicate that the selenium associated with the algal biomass is in the following forms: elemental selenium, organic selenium and sorbed selenite $\left(\mathrm{SeO}_{3}{ }^{2-}\right)$. The organic form is likely to be the most available to selenium-deficient crops (personal communication, R. Meyer, Department of Land, Air and Water, UC Davis). The solids will have to be evaluated for contamination by metals and agricultural chemicals prior to reuse.

\section{Wildlife protection}

Large-scale ABSR facilities are expected to pose much less hazard to wildlife than the surrounding drainage channels, evaporation ponds or drainage-contaminated wetlands. The concentration of selenium in the shallow HRPs will be similar to that in the drainage channels themselves, and HRPs will be continuously mixed by paddle wheels to minimize formation of sediment that would harbor invertebrates. Concentrated selenium will be sequestered in the deep sediments of the RPs. With RP depths of 20 feet to 25 feet, these sediments will be anoxic and will not attract waterfowl, since there is little or nothing to forage, even if diving water fowl could reach those 
depths. In contrast, wetlands with selenium-contaminated sediments and biota will require special management to prevent use by birds. Residual organic selenium in the ABSR Facility final effluent is a concern, however. Studies in progress will indicate what level of final clarification will be required to minimize this readily bioaccumulated form of selenium in the effluent.

\section{Treatment plant configuration}

We are evaluating two treatment plant configurations at the ABSR Facility in the Panoche Drainage District, each having potential cost advantages due to nitrate removal mechanism and internal nutrient recovery. In the lowcost plant configuration, or mode 1 , drainage water is brought into an HRP, where $15 \mathrm{mg} / \mathrm{L}$ to $30 \mathrm{mg} / \mathrm{L}$ of nitrate-nitrogen (nitrate- $\mathrm{N}$ ) is removed through assimilation by algae (fig. 1). The HRP effluent flows to the RP, where the algae settle and become bacterial feedstock. The bacteria remove dissolved oxygen and the remaining nitrate. The advantages of this mode are that an algae settling pond is not needed and less carbon feedstock is required for bacterial nitrate reduction, since algae take up a portion of the nitrate. The disadvantage is that carbon dioxide, phosphate and trace nutrients must be added to the HRP to achieve maximum algal growth.

In the high-removal efficiency plant configuration, or mode 2, drainage water and carbon feedstock are added

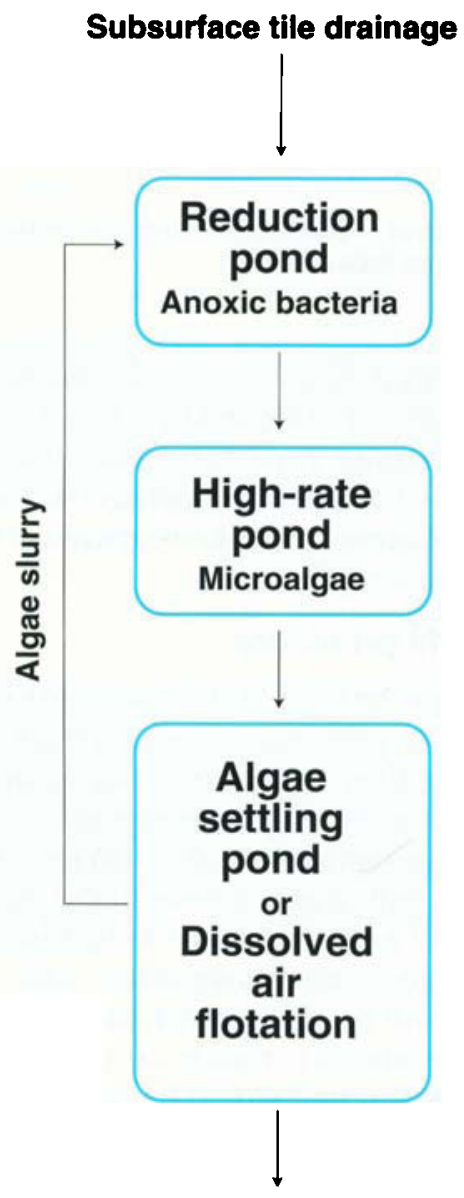

1. Organic carbon is added.

2. Oxygen is depleted. Carbon dioxide increases.

3. Nitrate is reduced to nitrogen gas.

4. Selenate is reduced to selenite or organic Se; selenite adsorbs to cationic particles or is reduced to elemental Se.

\section{Algae grow by assimilating carbon dioxide, ammonium and phosphate. 2. Soluble organic carbon is removed.}

Treated drainage return

1. Algae are harvested.

2. Water is clarified.

3. Residual selenite and particulate Se are removed. to the RP first (fig. 2). In the RP, bacteria deplete the dissolved oxygen, nitrate and selenium. The RP effluent containing bacterial metabolites such as ammonium, phosphate and dissolved carbon dioxide passes to the HRP. The metabolites become fertilizer for algae growth, thereby reducing the need for supplemental carbon dioxide and nutrients. The HRP algae are removed from the water by the algae settling pond or dissolved air flotation and are then added to the RP as carbon feedstock.

In mode 2, nitrate is removed by bacterial nitrate reduction only, which requires more carbon feedstock than mode 1 . However, in mode 2 , the RP influent is drainage water containing 8 $\mathrm{mg} / \mathrm{L}$ to $10 \mathrm{mg} / \mathrm{L}$ of dissolved oxygen. This oxygen concentration is two to three times lower than that of the HRP effluent pumped to the RP during mode 1 operation. The lower oxygen level requires less feedstock for oxygen removal. Some operational programs may use the diurnal cycle of low oxygen concentration characteristic of HRPs during the hours between midnight and sunrise.

In either treatment plant configuration, supplemental carbon feedstocks such as molasses or other food-processing wastes can be used in conjunction with the algae feedstock produced on site. Molasses is commonly used as a cattle feed supplement and is readily available in the San Joaquin Valley at a wholesale price of $\$ 60$ to $\$ 90$ per ton (USDA 1999). Both plant configurations and supplemental molasses are being evaluated at the Panoche Drainage District Facility.

\section{Panoche District facility}

The ABSR facility in the PDD consists of two parallel systems, each having a RP, a paddle-wheel-mixed HRP and an algae settling pond. So far, the two systems have been used to simultaneously compare mode 1 (low-cost configuration) and mode 2 (high-removal efficiency configuration) using the feedstocks algae and molasses. Having two parallel systems allows the operational parameters of one system to be varied while the other system is oper-

Fig. 2. Schematic of the ABSR technology operated in mode 2, the high-removal efficiency configuration receiving algae and molasses. 
ated as a control. A control system is essential to normalize the inevitable changes in drainage composition and weather conditions.

The 0.1-acre RPs are as deep as site constraints allowed - a 10-foot water depth. Greater depth would have helped prevent significant oxygen concentrations in the reaction zone near the floor of the ponds. To reduce wind-induced mixing and photosynthetic oxygenation by algae, we installed floating covers on these relatively shallow RPs. Full-scale RPs would probably not require surface covers due to their 20-to-25-foot depth and internal anoxic cells. During the course of the experiments, the RPs have been operated at hydraulic residence times (HRTs) from 14 to 60 days. The 0.1-acre, paddle-wheelmixed HRPs typically have generated algae concentrations of $100 \mathrm{mg} / \mathrm{L}$ to $300 \mathrm{mg} / \mathrm{L}$, with HRTs from 3 to 9 days. Carbon dioxide has been provided by bubbling the gas into a sump in each HRP. A baffle in the carbonation sump forces the water flow downward. Against this downward current, the carbon dioxide bubbles are suspended as they dissolve into the water. The 1,400-square-foot algae settling ponds with HRTs of 2 to 7 days provide a quiescent zone for the algae grown in the HRPs to settle. Overflow troughs in the settling ponds improve algae sedimentation by removing supernatant from the surface of the pond at a very low overflow velocity. The sloped floor and internal sump in each settling pond enable the harvesting of the algal biomass using a diaphragm pump.

Samples for water quality analysis and mass balance calculations are collected weekly and analyzed according to Standard Methods (APHA 1995). Flow rates and site observations are recorded every weekday by PDD personnel.

\section{Selenium removal rates}

Both treatment configurations demonstrated a regular seasonal fluctuation in nitrate and selenium removal, but the cumulative, 2-year selenate-Se mass removal for 1997 to 1998 was
$45 \%$ in the low-cost, mode 1 system and $80 \%$ in the high-removal efficiency, mode 2 system. The mode 1 system removed $70 \%$ of influent selenate June 1998 through November 1998, the most critical season for the Grasslands Bypass Project monthly load limits. During these 2 years, the mode 1 system received only algae feedstock while the mode 2 system received algae and molasses.

Dissolved air flotation clarification with ferric chloride coagulant is expected to remove residual selenite and particulate selenium, leaving selenate and soluble organic selenium in the effluent. We measure selenate and soluble organic selenium with a single analytical method and refer to them collectively as "selenate" in this discussion.

In short-term laboratory experiments, algae were about half as effective as molasses as a feedstock for bacterial nitrate reduction. But high selenium removals during the summer of 1998 in the mode 1 system indicate that in terms of nitrate removed per gram of algae added, the feedstock value of algae increases if they are allowed to undergo bacterial digestion over many months, as is the case in the RPs. The good summer performance also indicates that bacterial breakdown of algae is sensitive to water temperature. But regardless of feedstock, once nitrate- $\mathrm{N}$ was reduced to 5 $\mathrm{mg} / \mathrm{L}$ to $10 \mathrm{mg} / \mathrm{L}$, total soluble selenium was reduced.

Between April 1997 and January 1998, the mode 2 ABSR system consistently reduced nitrate to less than 10 $\mathrm{mg} / \mathrm{L} \mathrm{NO}_{3}{ }^{-}-\mathrm{N}$ until molasses addition was interrupted from mid-January to mid-February due to wet, impassable roads (fig. 3). During the April 1997 to January 1998 period of high nitrate removal, selenate removal averaged $82 \%$ from a mean of $422 \mu \mathrm{g} / \mathrm{L}$ as Se in the influent to a mean of $77 \mu \mathrm{g} / \mathrm{L}$ as selenium in the algae settling pond effluent. Selenate removal reached $5 \mathrm{~g} /$ day to $6 \mathrm{~g}$ /day as selenium during this period. Colder winter temperatures and the month of interrupted molasses addition presumably slowed bacterial activity and caused selenate removal to

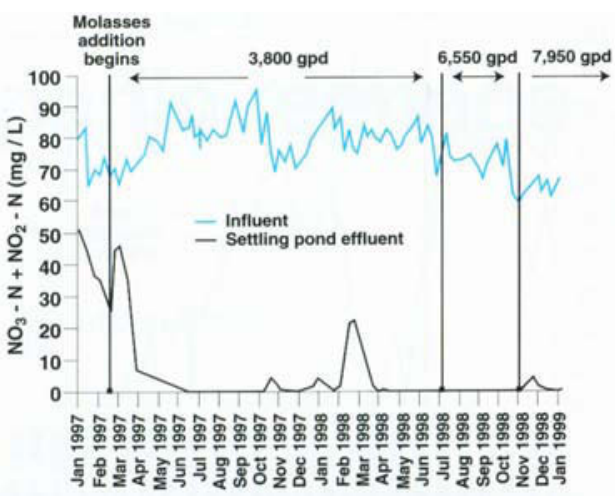

Fig. 3. Nitrate+nitrite concentrations in the mode 2 system.

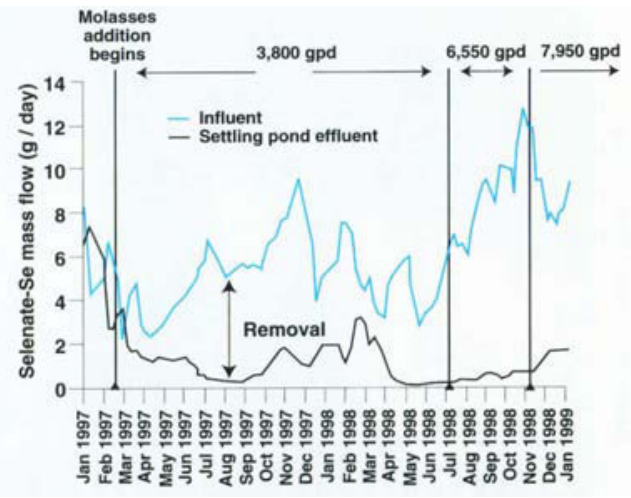

Fig. 4. Selenate-Se mass flow in the mode 2 system. Mass calculated as a 3-week moving average in grams/day. Average drainage water flow in gallons per day.

decrease to $68 \%$ from October 1997 through March 1998. From April 1998 through December 1998, selenium removal increased to $92 \%$, along with increased selenium loading to the system. The average influent selenate concentration was $402 \mu \mathrm{g} / \mathrm{L}$, which was reduced to an average of $32 \mu \mathrm{g} / \mathrm{L}$.

Between March 1997 and July 1998, the flow to the mode 2 system was 3,800 gallons per day, giving a hydraulic residence time of 66 days. The HRT in the mode 2 system was reduced to 38 days between July 1998 and November 1998, which increased the influent selenate load from about $6 \mathrm{~g} /$ day to $13 \mathrm{~g} /$ day. Despite the increased load, selenate mass in the effluent rose less than $1 \mathrm{~g}$ /day as Se (fig. 4). The flow was further increased at the end of November 1998 to reduce the HRT to 31 days.

After July 1997, the mode 1 system received only algal feedstock pro- 


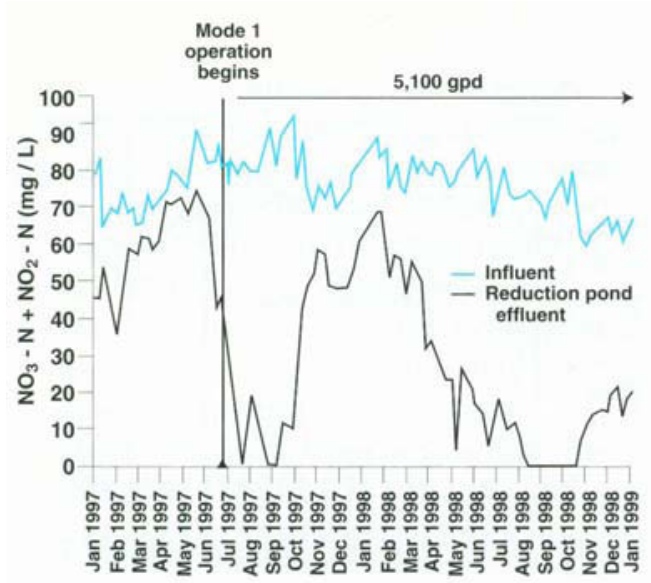

Fig. 5. Nitrate+nitrite concentrations in the mode 1 system.

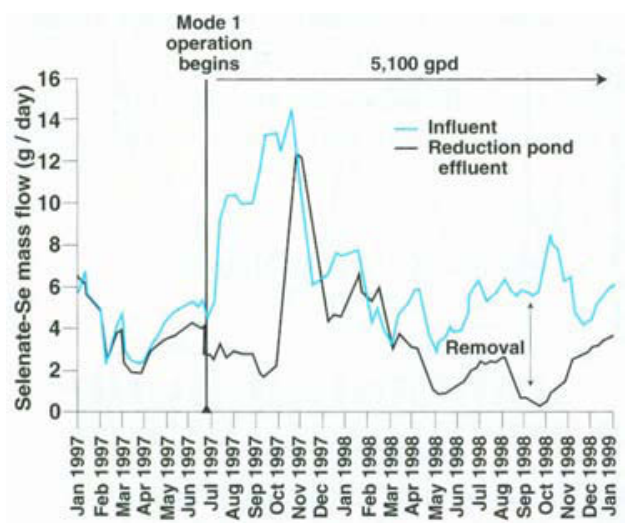

Fig. 6. Selenate-Se mass flow in the mode 2 system. Mass calculated as a 3-week moving average in grams/day. Average drainage water flow in gallons per day.

duced on site. Nitrate-N was removed from $80 \mathrm{mg} / \mathrm{L}$ to $90 \mathrm{mgL}$, to less than 1 $\mathrm{mg} / \mathrm{L}$ by September 1997, with an HRT of 49 days (fig. 5). Removal of nitrate decreased from October through March, which corresponds to the period of lower selenium removal in the mode 2 system. Nitrate and selenium removal generally increased from April 1998 through October 1998 (figs. 5 and 6). Selenate-Se mass removal averaged $64 \%$ during this period. Influent concentration averaged $431 \mu \mathrm{g} / \mathrm{L}$ as selenium, and the effluent averaged $155 \mu \mathrm{g} / \mathrm{L}$ as selenium.

The mode 1 system produced more sludge biomass per kilogram of selenium removal. The cost of sludge disposal will be a function of both transportation costs and the volume of biomass requiring removal. After 3 years of continuous operation, the mode 2 system has accumulated less than 6 inches of sludge in the reduction pond. Future expansion and cloning of the current ABSR system to other locations will need to compare the lower operating costs of the mode 1 system, using only algae feedstock, to the sludge disposal and performance advantages of the molasses-fed system. This trade-off may yield different results in different locations.

\section{Continuing work}

In mid-1999, the flow to the facility reached 27,000 gallons per day, giving an HRT of 25 days in the mode 1 system and 20 days in the mode 2 system. The long-term project goal is to further increase the flow rates through the ABSR Facility to achieve the greatest selenium mass reduction at the lowest cost for the PDD. A real-time, telemetered flow and water quality monitoring and control system has been installed at the facility to improve the efficiency of feedstock use and to maximize throughput without sacrificing selenium removal efficiency. The instrumentation chosen for the ABSR Facility is similar to that used by the district to routinely monitor drainage outflow; therefore the time and effort to instruct District personnel in the monitoring and control of plant operation will not be significant. Once this transfer of technology to the district is complete, a cost evaluation based on a full-scale facility design will be finalized. This will allow drainage district managers to make informed decisions on future investments in agricultural drainage treatment using the ABSR technology.

N.W.T. Quinn is Geological Scientist and Water Resources Engineer, Lawrence Berkeley National Laboratory; T.J. Lundquist is Assistant Specialist, F.B. Green is Assistant Research Engineer, and M.A. Zárate is Graduate Student, Applied Algae Research Laboratory, UC Berkeley; W.J. Oswald is Project Principal Investigator and Emeritus Professor of Civil and Environmental Engineering, and T. Leighton is Professor of $\mathrm{Mi}$ crobiology, UC Berkeley.
This project is currently supported by the U.S. Bureau of Reclamation through the CALFED Bay-Delta Program.

\section{References}

[APHA] American Public Health Association, American Water Works Association, and Water Environment Federation. 1995. Eaton AD, Clesceri LS, Greenberg AE (eds.). Standard Methods for the Examination of Water and Wastewater, 19th ed. $1205 \mathrm{p}$.

[CVRWQCB] Central Valley Regional Water Resources Control Board. 1999. Grasslands Bypass Monitoring Program Web site (www-esd.lbl.gov/quinn/Grassland. Bypassgrassland.htm). Sacramento, CA. Accessed November 2000.

[EPA] U.S. Environmental Protection Agency. 1987. Ambient Water Quality Criteria for Selenium-1987. Office of Research and Development, Environmental Research Laboratories, Washington, DC. Report \# EPA-440/ 5-87-006. $121 \mathrm{p}$.

Gerhardt MB, Green FB, Newman RD, et al. 1991. Removal of selenium using a novel algal-bacterial process. Res $\mathrm{J}$ Water Pollution Control Federation, July/August. p 799-805.

Gerhardt MB, Oswald WJ. 1990.

Microalgal-Bacterial Treatment for Selenium Removal from San Joaquin Valley Drainage Waters. Final report to Federal-State San Joaquin Valley Drainage Program, U.S. Bureau of Reclamation. Sacramento, CA. 242 p.

Lundquist TJ, Gerhardt MB, Green FB, et al. 1994. The algal-bacterial selenium removal system: Mechanisms and field study. In: Frankenberger WT, Benson SM (eds.). Selenium in the Environment. New York: Pergamon Press. p 251-78.

Ohlendorf HM, Hoffman DJ, Saiki MK, Aldrich TW. 1986. Embryonic mortality and abnormalities of aquatic birds - apparent impacts of selenium from irrigation drainwater.

Sci Total Environ 52:44.

Oswald WJ. 1985. Treatment of San Luis Drain water with microalgal bacterial system. Desk study report to U.S. Bureau of Reclamation. Sacramento, CA. 69 p.

Oswald WJ. 1988. Microalgae and wastewater treatment. In: Borowitzka MA, Borowitzka LJ (eds.). Micro-Algal Biotechnology. Cambridge, UK: Cambridge University Press. p 305-28.

Oswald WJ. 1990. Advanced integrated wastewater pond systems. Conference proceedings of "Supplying Water and Saving the Environment for Six Billion People" (Nov. 58), San Francisco, CA. p 73-81.

Quinn NWT, McGahan JC, Delamore ML. 1998. Innovative strategies reduce selenium in grasslands drainage. Cal $\mathrm{Ag} \mathrm{52(5):12-8.}$

[SWRCB] State Water Resources Control Board. 1989. Water Quality Control Plan (Basin Plan for the San Joaquin River Basin). Amendment Resolution \#1989-88, Sacramento, CA. 61 p.

[USDA] U.S. Department of Agriculture. 1999. Molasses Market News.-Springfield, IL. $1 \mathrm{p}$. 